\title{
OBITUARIES
}

\section{ARTHUR LOGAN TURNER}

THE announcement of Dr. Logan Turner's death on June 6th at his residence, 27 Walker Street, Edinburgh, from a cardiac attack, came as a shock to all his friends, particularly to those who, quite recently, had met him, when apparently he was in perfect health, and planning, in his usual cheery manner, for the near and distant future.

Arthur Logan Turner was born in Edinburgh in I865 and had just completed his seventy-fourth year. He was the second son of the late Sir William Turner, then Mr. Turner, Demonstrator of Anatomy under Prof. Goodsir. He was educated at Fettes College, and afterwards began his medical studies in the University of Edinburgh, where he graduated M.B., C.M., in I889. With the intention of becoming a general surgeon he acted as house surgeon and assistant to Prof. Annandale. An accident to a finger which, was feared, would handicap his manipulation, caused him to choose, in place of general surgery, specialization in diseases of the throat, nose and ear. In I89I he obtained the Fellowship of the Royal College of Surgeons of Edinburgh, and in 1894 the degree of M.D.

His first posts as a specialist were in the Deaconess Hospital, and, in 1906, in the Royal Infirmary. With the latter he was to be actively connected during the following eighteen years. $\mathrm{He}$ was then due to retire but his colleagues and the board of management valued his work and personality so highly as to take the unusual step of inviting him to continue in the department as Honorary Surgeon Consultant.

Throughout the war (I9I4-IgIg) he acted as aurist and laryngologist to the Second Scottish General Hospital with the rank of Captain in the R.A.M.C.(T.F.).

It is possible to make here only brief reference to improvements in the organization of the Department introduced by Turner on his becoming senior surgeon.

An important innovation, of which he highly approved, was the institution of Annual Reports from the Department. These usually contained a lengthy article by himself based on a collection of cases of the same or allied diseases which had been met with in his hospital and private practice over a number of years. Mr. J. S. Fraser, then his assistant, sometimes supplied a similarly prepared and beautifully illustrated otological paper; and occasionally one or two of the clinical assistants made short contributions. The 


\section{Obituaries}

last part of the Report contained Statistical Tables, worked out by the senior clinical assistant, including all the cases seen during the year. The affections of the various regions were grouped and counted. The operations were dealt with in the same manner. The huge accumulation of classified material thus gradually obtained has been of great value to subsequent investigators.

He was very systematic and, in order to have his cases classified, the reports kept in order, etc., he provided his own secretary.

A keen investigator himself, he gave every encouragement to the younger men in his Department, and to those who had begun practice but whose time was not fully occupied, to undertake research work. Dr. J. S. Fraser, his assistant for years, was a brilliant example of what might be accomplished-although in his case much must be attributed to his own ability and suitability for the problems which he set himself to solve.

Those who worked in the clinic with Turner recognized and often remarked that he treated his hospital cases as kindly and conscientiously as if they had been well-circumstanced and important private patients.

While in practice Turner made a number of valuable contributions of his own, or in association with others, to the literature of his speciality. The titles of most--if not all-of his Reprints, are noted in the Bibliography.

Several of the papers are of unusual length. One on "Bone cysts" in the accessory sinuses exceeds fifty pages. Turner had the good fortune to encounter several rare diseases, e.g. Rhinosporidiosis, Xanthoma Tuberosum, a peculiar form of Hyperplasia in the upper air tract, etc. Probably his best papers are those based on Pathological Anatomy, e.g. Paralysis of the Vocal Cord secondary to malignant tumour of the Mamma; Metastatic malignant tumour of the larynx secondary to Adeno-carcinoma of the right kidney; the submucous areolar tissue of the larynx and its significance in the spread of cedema; mucocele of the nasal accessory sinuses, etc. Also noteworthy are: The Bacteriology of Suppuration in the Accessory Sinuses in association with C. J. Lewis. Lastly, the extensive Researches in collaboration with F. Esmond Reynolds, on the Pathways of Pyogenic Infection to the Brain, to which further reference is made (v. i.).

In I898, the President and Council of the Royal College of Surgeons of Edinburgh invited Logan Turner to deliver a lecture before the Fellows. He selected as his subject, "The Illumination of the Air Sinuses of the Skull with some Observations upon the Surgical Anatomy of the Frontal Sinuses". In I899 the Council awarded him the Surgical Prize for an essay upon "The Racial Characteristics of the Frontal Sinuses, based upon an examination of 578 skulls". 


\section{Obituaries}

The subject matter contained in these communications served as the basis of a volume entitled "The Accessory Sinuses of the Nose, their surgical anatomy and the diagnosis and treatment of their inflammatory affections." This book, published in I9or, is still an admirable guide to the anatomy of the sinuses. A number of the beautiful plates have unfortunately been considerably reduced and are now utilized to illustrate the "Edinburgh Book" on diseases of the nose, etc.

Logan Turner was associated with several of his friends in the production of books and papers.

In I9I2 Mr. W. G. Porter and he published The skiagraphy of the Accessory Nasal Simuses. This was one of the earliest atlases of the kind and both the plates and letterpress were praiseworthy. It was dedicated to their former master, Dr. Peter M'Bride.

In I93I, he and Dr. F. Esmond Reynolds published a nine years' study entitled: Intracranial Pyogenic Diseases. This was a Pathological and Clinical Study of the pathways of infection from the face, the nasal and paranasal air-cavities to the brain. The Lancet in the course of a lengthy review stated: "This beautifully produced monograph follows the best traditions of Scottish medicine and is fit to be placed alongside the classic work of MacEwen on intracranial infections."

In r 924 , the first edition was published of what is generally known as the "Edinburgh Book" of Diseases of the Nose, Throat and Ear. Logan Turner was the prime mover and Editor of this conjoint production. He supplied the chapter dealing with the Anatomy of the Nasal and Paranasal Cavities and the section on the diseases of the latter. The remaining sections were contributed by five leading Edinburgh Ear and Throat Surgeons. The work was very well done and the volume, as it deserved, has attained a world-wide reputation. The fourth edition is now on sale and, unlike many medical works, has been a financial success. Turner recently stated that he had decided to resign the editorship, as, for a number of years, he had been out of clinical practice.

On behalf of the Lister Centenary Committee of the British Medical Association, Logan Turner edited the Centenary Volume, 1827-1927, on Joseph, Baron Lister.

In his Foreword the Editor states that "The main idea underlying the preparation of the book has been to reproduce, partly by transcribing his own words and partly through the language of others, the surgical conditions of the period, his labours to solve the problem of sepsis, and the successful realization which attended his efforts."

The contents consist mainly of interesting articles and reminiscences contributed by-Sir George T. Beatson, Mr. Alexander Miles, Sir John Fraser, and others. 


\section{Obituaries}

The success attending the production of this charming book demonstrated the Committee's happy choice of Logan Turner as Editor.

Logan Turner wrote and published in I9I9 a life of his father entitled: "Sir William Turner, K.C.B., F.R.S., A Chapter in Medical History."

This work outlines the life of a highly talented man with a strong personality. He was invited to come to Edinburgh in 1854 to take up the duties of Demonstrator of Anatomy under Professor Goodsir. When he arrived, with the exception of his "chief ", he knew no one in the city. On Goodsir's death in 1867 he succeeded to the Chair. In I886 he was knighted. In I903 he was appointed Principal and Vice-Chancellor of the University. He was a member of the General Medical Council for nearly thirty years during six of which he was President. His successor, Sir Donald Macalister, stated that the Council never had an abler, wiser or more just President.

The books deals, not only with the life of this extraordinarily capable man, but also supplies an interesting and instructive commentary on the progress of medical education during his sixty-two years of service to the University of Edinburgh when "he combined in his own person the teacher, the scientific investigator and the administrator."

After his retiral from practice Logan Turner devoted much of his time to the study of the history of the Edinburgh Medical School. As an outcome of his research a large handsome volume appeared in I937 entitled: Story of a Great Hospital, The Royal Infirmary of Edinburgh, I729-1929.

The book opens with "A brief sketch of the main centres of learning which throughout the ages, have influenced the progress of medicine." The author gradually leads up to the medical school at Leiden in the seventeenth and eighteenth centuries when its high reputation, especially during Boerhaave's activity, attracted young Scotsmen. Turner maintains that the Hippocratic tradition, and recognition of the value of combined university and hospital education came to Edinburgh through the school at Leiden.

In October, I937, he went to Leiden as a delegate from the University of Edinburgh (Faculty of Medicine) and presented a congratulatory address on the occasion of the Commemoration of the Tercentenary of clinical teaching in the University of Leiden.

Subsequently he prepared notes and made researches into the early relations between the University in Holland and that in Scotland, in the hope of ultimately writing a book on this subject. Eight days prior to his death he was planning to visit Leiden again.

The latter part of the "Story" deals at considerable length with-the growth of the Hospital from its foundation in 1739 ; the staff, especially the more noted physicians and surgeons; the 


\section{Obituaries}

administration; finances, etc., up to the bicentenary year I929. The work evinces high scholarship and extensive research, and is written in a charming style.

Turner was gratified with the very favourable opinions expressed as to his work, and the excellent press notices it received. In a letter accompanying a copy, he wrote: "I enjoyed its compilation although it has taken me nearly four years, and now I miss it."

The Logan Turner Prize. For nine years (I92I-I929) Logan Turner and J. S. Fraser were joint Editors of the Journal of Laryngology and Otology. During that period the Journal, which had languished in consequence of the war, underwent great improvement in the quality and amount of its contents. When Turner resigned office, in recognition of his work and success as Editor, he was presented with a substantial sum of money subscribed by his fellow laryngologists and otologists. At his request the money was used to establish a prize to be presented every five years for the best piece of original work. This is now known as the Logan Turner Prize.

For ten years (1928-37) Logan Turner was Editor of The University of Edinburgh Journal, a periodical published twice yearly by the University of Edinburgh Graduates' Association.

Travelling may be claimed as one of Turner's hobbies, and long ago he looked forward to travelling as probably the pleasantest recreation he could have when retired. He visited America and Canada several times and in both countries was on intimate terms with some of the leading oto-laryngologists. He was a member of the Collegium-Oto-Rhino-Laryngologicum Amicitae Sacrum, and of the Visiting Association of Throat and Ear Surgeons of Great Britain. He thus had opportunities, which he did not neglect, of visiting, in company with his fellow members, the hospitals and clinics of the best representatives of the speciality in most of the continental countries.

One who knew him intimately has given the writer a few notes as to certain of his sporting proclivities. "He did not play himself, but every Saturday afternoon in winter he went to a rugger match, and in summer he closely followed cricket. As a matter of fact he was interested in most forms of sport; and his knowledge of golf, boxing, amateur athletics, etc., was encyclopædic.

" Every ten years a club is formed, the membership of which is limited to graduates in that decade. Turner, having qualified in I 889, belonged to the Octogenarians. They met in winter for a dinner and in summer for dinner and golf. Every summer for the latter event Turner brought from his box-room the only golf club he ever possessed-a cleek-and played a few holes. 'Turner and his cleek' were an 'Institution' well known, not only to his fellow Octogenarians, but also to all his Edinburgh friends." 


\section{Obituaries}

It is not surprising that the son of a man so talented as Sir William Turner should have inherited some of his father's great qualities and been influenced by his example. We can recognize in Logan Turner natural ability, capacity for hard work and determination to carry it through. He became a successful organizer, a fluent speaker and concise writer with a good style. While he was respected for these and other admirable qualities, he was valued and loved by those who knew him for his geniality and modesty, lack of self-seeking, quiet kindliness to all, and desire to be of service. Loyalty was one of his predominating characteristics. Loyalty to his friends, to his University and to his City. An unkind remark about Logan Turner was never heard.

He was unmarried. Deep sympathy is felt for his sister, Miss Turner, who resided with him, and was his frequent companion when on holiday, and his surviving brother, Dr. Aldren Turner, Consulting Neurologist to King's College Hospital, London.

\section{HONOURS}

Logan Turner received many honours at home and abroad. The unusually long subjoined list of these, conferred on a man so modest and lacking in self-seeking, is a striking testimony to his fame and achievements.

\begin{tabular}{|c|c|}
\hline $\begin{array}{l}1925-27 \\
1926\end{array}$ & $\begin{array}{l}\text { President of the Royal College of Surgeons, Edinburgh. } \\
\text { Honorary LL.D., Edinburgh University. }\end{array}$ \\
\hline 1927 & $\begin{array}{l}\text { Honorary Fellow of the Royal College of Physicians, } \\
\text { Edinburgh. }\end{array}$ \\
\hline 1927 & President of the Medico-Chirurgical Society of Edinburgh. \\
\hline $924-25$ & $\begin{array}{l}\text { President of the Section of Laryngology, Royal Society of } \\
\text { Medicine, London. }\end{array}$ \\
\hline I92I-22 & $\begin{array}{l}\text { President of the Section of Otology, Royal Society of } \\
\text { Medicine, London. }\end{array}$ \\
\hline 1927 & $\begin{array}{l}\text { President of the Section of Otology and Laryngology, } \\
\text { British Medical Association, meeting in Edinburgh. }\end{array}$ \\
\hline 1923 & Semon Lecturer in Laryngology, University of London. \\
\hline 1932 & $\begin{array}{l}\text { President of Scottish Society of Otology and Laryngology } \\
\text { (First Chairman, I9Io.) }\end{array}$ \\
\hline \multirow[t]{9}{*}{1932} & $\begin{array}{l}\text { Vice-President of Section of Oto-Laryngology, Centenary } \\
\text { Meeting of British Medical Association in London. }\end{array}$ \\
\hline & Honorary Member of the following Societies: \\
\hline & American Medical Association. \\
\hline & Austrian Otological Society. \\
\hline & Scottish Society of Otology and Laryngology. \\
\hline & $\begin{array}{l}\text { Honorary Fellow of the American Laryngological, } \\
\text { Rhinological and Otological Society. }\end{array}$ \\
\hline & $\begin{array}{l}\text { Corresponding Fellow of the American Laryngological } \\
\text { Association. }\end{array}$ \\
\hline & Corresponding Member of the Vienna Laryngologice \\
\hline & $\begin{array}{l}\text { Rhinological Society, and of the French Society } \\
\text { Otology and Laryngology. }\end{array}$ \\
\hline
\end{tabular}




\section{Obituaries}

\section{PAPERS BY A. LOGAN TURNER}

OR IN ASSOCIATION WITH OTHERS

I. " Naso-pharyngeal Adenoids : a Clinical and Pathological Study." By Dr. P. M'Bride and A. L. Turner. Edin. Med. Journ., I 897 .

2. "Clinical Cases from the Ear and Throat Department, Edinburgh Royal Infirmary." By Dr. P. M'Bride and A. L. Turner. Edin. Med. Journ., I898.

3. "On the Illumination of the Air Sinuses of the Skull." By A. L. Turner. Edin. Med. Journ., I898.

4. "On the Causation of the Congenital Stridor of Infants." By John Thomson and A. L. Turner. Brit.Med.Journ., Dec. I90o.

5. "The Accessory Sinuses of the Nose. Their Surgical Anatomy, etc." Edin., Wm. Green \& Sons, Igor.

6. "The Submucous Areolar Tissue of the Larynx and its Significance in the spread of Edema." By A. L. Turner. Edin. Med. Journ., 1902.

7. "A Contribution to the Pathology of 'Bone Cysts' in the Accessory Sinuses of the Nose." By A. L. Turner. Edin. Med. Journ., I903-4.

8. "The Operative Treatment of Chronic Suppuration in the Frontal Sinus." By A. L. Turner. Edin. Med. Journ., 1905.

9. "A Case of Keratosis of the Larynx." By A. L. Turner. Edin. Med. Journ., I906.

Io. "On Congenital Stridor (Laryngeal and Tracheal)." By A. L. Turner. Brit. Med. Journ., I906.

II. "Mucocele of the Accessory Nasal Sinuses." By A. L. Turner. Edin. Med. Journ., 1907.

12. "Some points of interest in the Surgery of the Ear, Nose and Throat." By A. L. Turner and J. S. Fraser. Edin. Med. Journ., 1908 .

13. "The Orbital Complications of Suppuration in the Frontal and Ethmoidal Sinuses." By A. L. Turner. Edin. Med. Journ., rgor.

14. " Notes upon Fourteen Cases of Intra-Cranial Disease complicating Middle-Ear Suppuration." By A. L. Turner. Journ. Lar., Rhin., and Otol., I909.

15. "A further study of the Bacteriology of Suppuration in the Accessory Sinuses of the Nose." By A. L. Turner and C. J. Lewis. Journ. Lar., Rhin., and Otol., I9ro.

16. "A Clinical and Bacteriological Study of 36 Cases of Mastoid Suppuration including ro cases of Intra-Cranial Complication." By A. L. Turner and F. Esmond Reynolds. Journ. Lar., Rhin., and Otol., I9I I.

17. "The spread of Bacterial Infections from the Nasal and Nasopharyngeal Cavities by way of Lymphatic Channels." By A. L. Turner. Journ. Lar., Rhin., and Otol., Igr I.

18. "A Contribution to Serum and Vaccine Therapy in the Treatment of Intra-Cranial Complications of Middle Ear Suppuration." By A. L. Turner. Journ. Lar., Rhin., and Otol., I912. 


\section{Obituaries}

19. " Direct Laryngoscopy, Tracheo-Bronchoscopy and Esophagoscopy." By A. L. Turner and J. S. Fraser. I9I3.

2o. "Malignant Disease of the Esophagus, with special reference to Carcinoma of the Upper End: based upon 68 cases of Tumour." By A. L. Turner. Journ. Lar., Rhin., and Otol., I9I3.

21. "A Survey of the work done in Britain on the Diseases of the Nasal Cavities and their Accessory Sinuses." By A. L. Turner and W. G. Porter. Journ. Lar., Rhin., and Otol., I9I3.

22. "A Peculiar Form of Hyperplasia of the Mucous Membrane of the Upper Respiratory Tract." By A. L. Turner. Journ. Lar., Rhin., and Otol., I9I4.

23. "Stenosis of the Larynx in Children following Intubation and Tracheotomy." By A. L. Turner. Journ. Lar., Rhin., and Otol., 1916.

24. "Immunity in Health: the Function of the Subepithelial Lymphatic Glands." By A. L. Turner. Journ. Lar. and Otol., 192 I.

25. "The Education and Qualification of the Specialist." By A. L. Turner. Journ. Lar. and Otol., 1921.

26. "Two Cases of Traumatic Adhesions of the Soft Palate to the Posterior Pharyngeal Wall." By A. L. Turner. Journ. Lar. and Otol., I92I.

27. "Paralysis of the Vocal Cords secondary to Malignant Tumour of the Mamma." By A. L. Turner. Journ. Lar. and Otol., I92I.

28. " The Structural Type of the Mastoid Process based upon Skiagraphic Examination of Ioo Crania of Various Races." By A. L. Turner and Major W. G. Porter. Journ. Lar. and Otol., I922.

29. "The Position of Laryngology and Otology in the Medical Curriculum in Great Britain." By A. L. Turner. Journ. Lar. and Otol., 1922.

3o. "An Uncommon Tonsillar Appendage and its Relation to Cartilage Formation in the Tonsil." By A. L. Turner and Thomas Sprunt. Journ. Lar. and Otol., 1923.

31. "The Advancement of Laryngology and Otology: a Plea for adequate Training and closer Co-operative Action." "The Semon Lecture." By A. L. Turner. Journ. Lar. and Otol., I923.

32. "A Case of Rhinosporidiosis." By Prof. J. H. Ashworth and A. L. Turner. Journ. Lar. and Otol., 1923.

33. "Metastatic Malignant Tumour of the Larynx, secondary to Adenocarcinoma of the Right Kidney." By A. L. Turner. Journ. Lar. and Otol., I924.

34. "The Relation of Visual Disturbances with Affections of the Nasal Cavities and Posterior Group of Sinuses." By A. L. Turner. Journ. Lar. and Otol., 1924.

35. "Abductor Paralysis of the Right Vocal Cord subsequent to Scirrhus Cancer of the Left Mamma." By A. L. Turner. Journ. Lar. and Otol., 1925. 


\section{Obituaries}

36. "A Case of Xanthoma Tuberosum with Nodules of Xanthoma on Mucous Membrane of the Respiratory Tract." By A. L. Turner. Journ. Lar. and Otol., 1925.

A Study of the Paths of Infection to the Brain, Meninges, and Venous Blood Sinuses from Neighbouring Peripheral Foci of Inflammation.

37. I.- "Furuncle of R. Nasal Vestibule: Thrombosis of Cavernous Sinuses : Leptomeningitis : Death : Autopsy." By A. L. Turner and F. Esmond Reynolds. Journ. Lar. and Otol., 1926.

38. II.- "Suppuration in R. Posterior Ethmoidal and Sphenoidal Sinuses: Orbital Abscess: Cavernous Sin. Thrombosis: Leptomeningitis : Operation: Death : Autopsy." By A. L. Turner and F. Esmond Reynolds. Journ. Lar. and Otol., I926.

39. 'III.-" Nasal Mucous Polypi: Intranasal Operation on Ethmoidal Air Cells: Purulent Leptomeningitis: Death : Autopsy." By A. L. Turner and F. Esmond Reynolds. Journ. Lar. and Otol., 1926.

40. IV.- "Acute Infection of L. Sphenoidal Sinus: Cavernous Sinus Thrombosis: Leptomeningitis: Operation: Death : Autopsy." By A. L. Turner and F. Esmond Reynolds. Journ. Lar. and Otol., 1927.

4I. V.- “ Nasal Mucous Polypi: Intranasal Operation on Ethmoidal Air Cells: Purulent Leptomeningitis : Death : Autopsy." By A. L. Turner and F. Esmond Reynolds. Journ. Lar. and Otol., 1927.

42. VI.-“"Meningococcal Leptomeningitis: Death: Autopsy : Inflammatory Changes in Sphenoidal Air Sinuses and early Cav. Sin. Thromb. (Streptococcal): A case illustrating Double Infection." By A.L. Turner and F. Esmond Reynolds. Journ. Lar. and Otol., I928.

43. VII.-." Acute Suppuration in the Accessory Sinuses: Cav. Sin. Thromb.: Acute Leptomeningitis: Death : Autopsy." By A. L. Turner and F. Esmond Reynolds. Journ. Lar. and Otol., 1928.

44. VIII.- "Chronic Suppuration in the Ethmoidal and Sphenoidal Air-Sinuses (Bilateral): Acute Leptomeningitis of Nasal Origin arising spontaneously: Death : Autopsy." By A. L. Turner and F. Esmond Reynolds. Journ. Lar. and Otol., 1929.

45. Labyrinthitis, A Complication of Middle Ear Suppuration. A Clinical and Pathological Study." By A. L. Turner and J. S. Fraser. Journ. Lar. and Otol., Part I, I927; Part II, I928; Part III, I932.

46. "The Problem of Otosclerosis." By A. L. Turner. Journ. Lar. and Otol., 1928.

47. "Editorial: The Journal of Laryngology and Otology." By A. L. Turner and J. S. Fraser. Journ. Lar. and Otol., 1928. 


\section{Obituaries}

48. "Valedictory Address to the Medico-Chirurgical Society of Edinburgh." By A. Logan Turner, President, M.D., LL.D., F.R.S.E., Edin. Med. Journ., I930.

49. "Some Impressions that Remain." By A. L. Turner. Journ. Lar. and Otol., 1936.

A. Brown Kelly.

\section{ARTHUR WELLESLEY SANDFORD}

\section{Born I 858}

SANDFORD joined the writer, Macintyre and Milligan in maintaining the Journal of Laryngology, Rhinology and Otology at a time when the demand for it was insufficient to allow of it being carried on without the financial support and active co-operation of those few who believed in it and handed it on with all goodwill to their successors and a writer in the Times has signalized his many remarkable qualities. In the little intimate circle of his colleagues who with him kept the Journal of Laryngology going his arrival was always a cause for rejoicing. When difficulties or differences of opinion marred the working of the little syndicate Sandford's beaming countenance shed sunlight on the proceedings and his musical persuasive utterances smoothed out all wavelets of dissension. Unhappily his colleagues have nearly all passed away but as long as they survived they retained a warm place in their hearts for Arthur Sandford.

JAMEs DUndaș-Grant. 